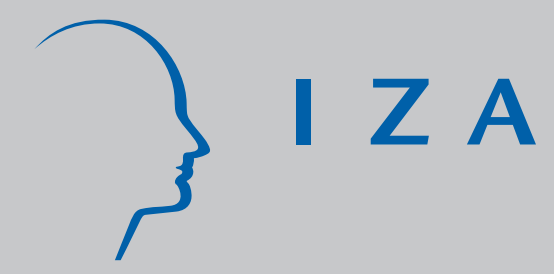

IZA DP No. 917

A Note on the Redistributive Effect of Immigration

Rob Euwals

Hans Roodenburg

October 2003 


\title{
A Note on the Redistributive Effect of Immigration
}

\author{
Rob Euwals \\ $C P B$, The Hague, \\ CEPR and IZA Bonn \\ Hans Roodenburg \\ $C P B$, The Hague \\ Discussion Paper No. 917 \\ October 2003
}

\author{
IZA \\ P.O. Box 7240 \\ D-53072 Bonn \\ Germany \\ Tel.: +49-228-3894-0 \\ Fax: +49-228-3894-210 \\ Email: iza@iza.org
}

This Discussion Paper is issued within the framework of IZA's research area Mobility and Flexibility of Labor. Any opinions expressed here are those of the author(s) and not those of the institute. Research disseminated by IZA may include views on policy, but the institute itself takes no institutional policy positions.

The Institute for the Study of Labor (IZA) in Bonn is a local and virtual international research center and a place of communication between science, politics and business. IZA is an independent, nonprofit limited liability company (Gesellschaft mit beschränkter Haftung) supported by Deutsche Post World Net. The center is associated with the University of Bonn and offers a stimulating research environment through its research networks, research support, and visitors and doctoral programs. IZA engages in (i) original and internationally competitive research in all fields of labor economics, (ii) development of policy concepts, and (iii) dissemination of research results and concepts to the interested public. The current research program deals with (1) mobility and flexibility of labor, (2) internationalization of labor markets, (3) welfare state and labor market, (4) labor markets in transition countries, (5) the future of labor, (6) evaluation of labor market policies and projects and (7) general labor economics.

IZA Discussion Papers often represent preliminary work and are circulated to encourage discussion. Citation of such a paper should account for its provisional character. A revised version may be available on the IZA website (www.iza.org) or directly from the author. 
IZA Discussion Paper No. 917

October 2003

\section{ABSTRACT}

\section{A Note on the Redistributive Effect of Immigration*}

In this paper, we study gains and losses that accrue to natives because of immigration. The gain on the aggregated level is called the 'immigration surplus', which can be seen as analogous to a consumer surplus. We derive changes in the earnings of native owners of production factors by employing a stylized model with capital and two types of labour. We claim that the changes in earnings are larger than reported by previous studies, and we propose a new method to tally them up to the immigration surplus.

JEL Classification: D30, D60, J31, J61

Keywords: immigration, wages, economic welfare, redistribution

Corresponding author:

Rob Euwals

CPB

P.O.Box 80510

2508 The Hague

The Netherlands

Email: r.w.euwals@cpb.nl

\footnotetext{
* The authors wish to thank Nick Draper, Ate Nieuwenhuis, Daniel van Vuuren and participants of
} seminars at $\mathrm{CPB}$ and IZA for valuable comments. 
Introduction

This paper uses a simple economic framework elaborated by Borjas (1999) to calculate gains and losses that accrue to different groups in a host country because of immigration. Natives benefit from immigration on the aggregated level as long as immigrants and natives differ in their productive endowments, for instance with respect to skills. The benefits are, however, not evenly distributed over the native population: natives who have productive endowments that complement those of immigrants gain, while natives who have endowments that compete with those of immigrants lose. In this paper, we claim that the gains and losses within the native population are larger than reported by Borjas.

For the sake of transparency, we first consider an economy with two production factors: capital and labour. We show that immigration leads to an overall net gain for natives ('the immigration surplus'). The net gain is, however, composed of gains and losses of different groups within the population. We deviate from Borjas by proposing a different method to tally up the gains and losses. We provide simulations to illustrate the differences in outcomes between the methods. Next, we show how our method generalizes to an economy with capital and two types of labour as production factors.

\section{Model with two production factors}

Suppose the production technology in the host country can be summarized by a twicedifferentiable and continuous linear homogeneous aggregate production function with two inputs, capital $K$ and labour $L$, so that output $Q=f(K, L)$. The work force $L$ contains $N$ native and $M$ immigrant workers, and all workers are perfect substitution in production $(L=M+N)$. Natives own the entire capital stock in the host country. Finally, the supplies of native and immigrant workers do not react to changes in wages (i.e. the supplies are perfectly inelastic).

In a competitive economy, each factor price equals the respective value of marginal productivity. Let the price of output $\mathrm{Q}$ be the numeraire. The rental rate of capital in the preimmigration equilibrium is $r_{0}=f_{K}(K, N)$ and the price of labour is $w_{0}=f_{L}(K, N)$. Because the aggregate production function exhibits constant returns to scale, the entire output is distributed to the owners of capital and to workers. In the pre-immigration regime, the national income accruing to natives $Q_{N}$ is given by

$Q_{N}=r_{0} K+w_{0} L$ 


\section{Figure 2.1 The immigration surplus}

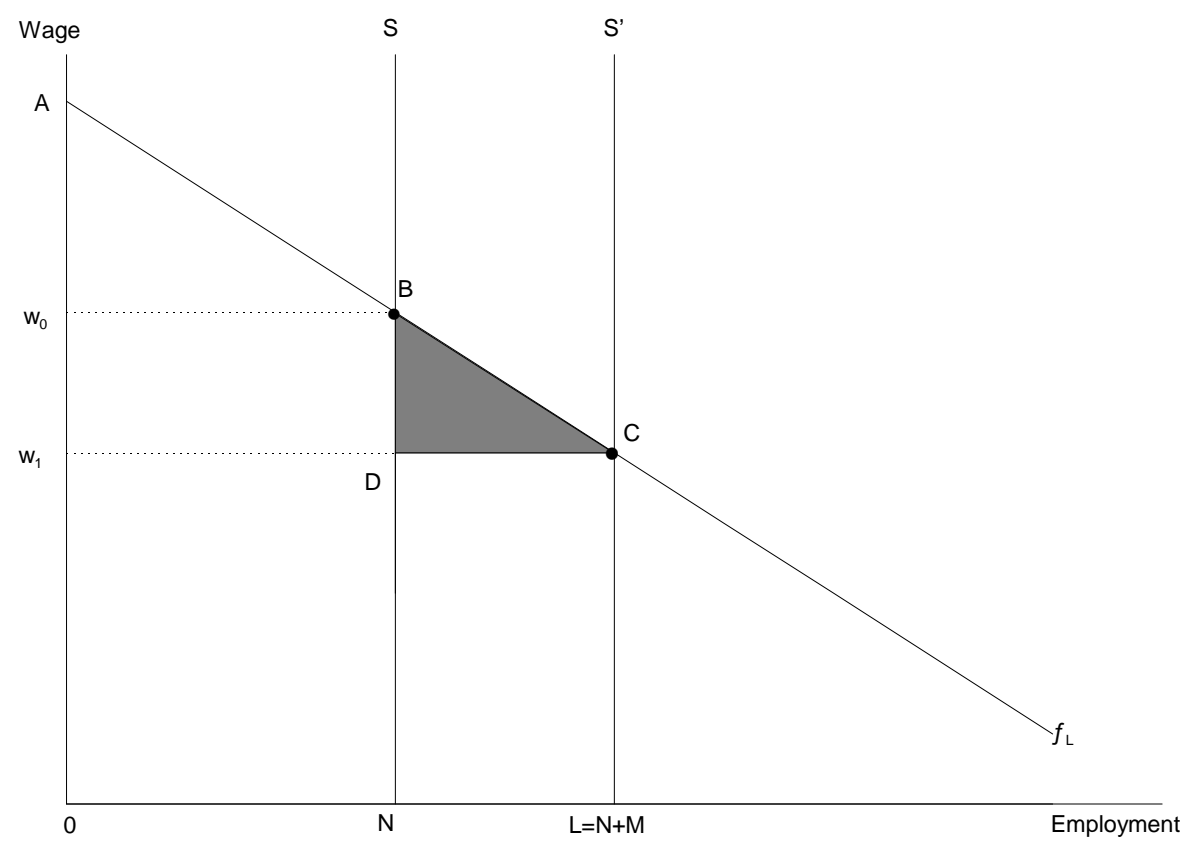

Figure 2.1 illustrates the demand for labour at different wages in the form of a (compensated) demand curve $f_{L}$. The labour demand curve will not be affected by immigration, as we assume the stock of capital to be fixed. Curve $S$ represents labour supply without immigrants and thus with a number of $N$ native workers, while $S$ ' represents labour supply with an additional number of $M$ immigrant workers. Flexible wages allow the economy to reach equilibrium in which supply and demand meet. In the initial equilibrium $B$ the wage is equal to $w_{0}$. The entry of $M$ immigrants shifts the labour supply curve, leading to a new equilibrium $C$ with wage $w_{0}$.

How does immigration affect the incomes of the different groups of the native population? We do a welfare analysis using the property that the area under the labour demand curve is equal to the economy's total output. Figure 2.1 shows that immigration increases total output from trapezoid $A B N O$ to $A C L O$, implying a gain of trapezoid $B C L N$. A large part of it, rectangle $D C L N$, will be paid to immigrants in the form of wages. The rest, triangle $B C D$, will accrue to natives. This increase in total earnings is called 'the immigration surplus'.

As the demand curve may be nonlinear, triangle $B C D$ is an approximation of the immigration surplus $\Delta Q_{N}$. The area of the triangle is given by $1 / 2\left(w_{0}-w_{1}\right) M$. Furthermore, as we cannot observe wages with and without immigration at the same time we also need to approximate the difference in wages. We use a first order approximation: $\left(w_{0}-w_{1}\right) \approx-(\partial w / \partial L) M$. Thus, the immigration surplus (as a fraction of national income $Q$ ) will be approximated as follows: 
$\frac{\Delta Q_{N}}{Q} \approx \frac{\frac{1}{2}\left(w_{0}-w_{1}\right) M}{Q} \approx \frac{-\frac{1}{2}\left(\frac{\partial w}{\partial L} M\right) M}{Q}=-\frac{1}{2}\left(\frac{w L}{Q}\right)\left(\frac{\partial w}{\partial L} \frac{L}{w}\right)\left(\frac{M}{L}\right)^{2}=-\frac{1}{2} \alpha_{L} \varepsilon_{L L} m^{2}$

where $\alpha_{L}$ is labour's share of national income; $\varepsilon_{L L}$ is the elasticity of factor price for labour (holding marginal cost constant); and $m$ is the fraction of the work force that is immigrant.

A 'back-of-the-envelope' calculation for the United States, with a share of labour in national income $\alpha$ of about $70 \%$, an elasticity of factor price for labour $\varepsilon_{L L}$ of -0.3 (Hamermesh, 1993) ${ }^{2}$ and a fraction of immigrants in the labour force $m$ of about $10 \%$, gives an immigration surplus on the order of $0.1 \%$ of GDP.

Immigration redistributes income from labour to capital. In terms of Figure 2.1, native workers lose the area in rectangle $w_{0} B D w_{l}$, and this quantity plus the immigration surplus accrues to capital owners. Expressed as a fraction of GDP, the immigration surplus consists of the net changes in incomes of native workers and capital owners:

$$
\frac{\Delta Q_{N}}{Q}=\frac{K\left(r_{1}-r_{0}\right)}{Q}+\frac{N\left(w_{1}-w_{0}\right)}{Q}
$$

Both the gain of capital owners and the loss of workers may be calculated by using the same first order approximation as we used for the previous equation: $\left(w_{0}-w_{1}\right) \approx-(\partial w / \partial L) M$ and $\left(r_{0}-r_{l}\right) \approx-(\partial r / \partial L) M$. The resulting immigration surplus can be written as a weighted sum of the immigration elasticities of factor prices: ${ }^{3}$

$$
\frac{\Delta Q_{N}}{Q} \approx \alpha_{K}^{m}\left[\frac{\partial r}{\partial M} \frac{M}{r}\right]+\alpha_{L}^{m}\left[\frac{\partial w}{\partial M} \frac{M}{w}\right]
$$

with weighting factors $\alpha_{K}{ }^{m}=\alpha_{K}$ and $\alpha_{L}{ }^{m}=(1-m) \alpha_{L}$ and immigration elasticities of factor prices:

$$
\begin{gathered}
\frac{\partial r}{\partial M} \frac{M}{r}=\varepsilon_{K L^{m}} \\
\frac{\partial w}{\partial M} \frac{M}{W}=\varepsilon_{L L^{m}}
\end{gathered}
$$

\footnotetext{
${ }^{2}$ Hamermesh (1993) concludes that the elasticity of labour demand is about -0.3. Under the assumptions of a competitive economy and a labour's share in national income of $70 \%$, the elasticity of factor price of labour is about -0.3 as well.

${ }^{3}$ From here on we start to deviate from Borjas (1999)
} 
These elasticities can be interpreted as the effect of immigration on factor prices as they consist of labour supply elasticities of factor prices, $\varepsilon_{K L}$ and $\varepsilon_{L L}$, times the amount of immigration $m$.

As the immigration surplus of equation (2.2) and the gains and losses of the production factors of equation (2.4) are based on first order approximations, it is not obvious that tallying up the gains and losses leads to the same size of the immigration surplus. In fact, using the identity $\alpha_{K} \varepsilon_{K L}+\alpha_{L} \varepsilon_{L L}=0$, it can be shown that the immigration surplus of the latter equation is twice as large as the one reported by the former equation.

\begin{tabular}{|c|c|c|c|c|}
\hline \multirow[t]{2}{*}{ Simulation of ec } & ic costs and ben & n immigrat & & \\
\hline & \multicolumn{3}{|l|}{ On the basis of } & Method 3 \\
\hline Earnings of capital (rental rate) ${ }^{b}$ & 7.00 & 6.67 & 3.50 & 7.00 \\
\hline Earnings of labour (wage) ${ }^{b}$ & -3.00 & -3.00 & -1.50 & -3.00 \\
\hline \multicolumn{2}{|l|}{ Immigration surplus $^{c}$} & 0.11 & 0.11 & 0.11 \\
\hline \multicolumn{2}{|l|}{ Total native earnings of capital $^{c}$} & 2.00 & 1.05 & 2.10 \\
\hline \multicolumn{2}{|l|}{ Total native earnings of labour ${ }^{c}$} & -1.89 & -0.94 & -1.99 \\
\hline \multicolumn{5}{|c|}{$\begin{array}{l}\text { (a) All simulations assume that the labour share in national income } \alpha \text { is } 70 \% \text {; that the elasticity of factor price for labour } \\
\text { supply } \varepsilon_{L L} \text { is }-0.3 \text { and that the fraction of immigrants is the workforce is } 10 \% \text {. The explanation of the calculation methods } \\
\text { can be found in the text of this section. }{ }^{\left({ }^{(b)}\right.} \text { Change in percentages. }{ }^{(c)} \text { Change in percentages of GDP. }\end{array}$} \\
\hline
\end{tabular}

\section{Calculation methods}

In this paper, we maintain the hypothesis that equation (2.2) gives the most reasonable approximation of the immigration surplus. Borjas (1999) does so as well. Arguments in favour of this approximation are that it is derived directly from Figure 2.1 and that the literature on consumer surpluses uses a same kind of approximation. The ultimate goal of this paper is therefore to find an approximation method for the amount of redistribution that is consistent with the immigration surplus of equation (2.2).

We discuss different methods to approximate the amount of redistribution. For illustration purposes, Table 2 presents the effects of immigration on earnings and total earnings for the same example as used above. The first column presents the effect on earnings: in case of an elasticity of factor price for labour $\varepsilon_{L L}$ of -0.3 , a fraction of immigrants of $10 \%$ implies a decrease in wages of $3 \%$ and an increase in the return of capital of $7 \%$ (using the identity $\alpha_{K} \varepsilon_{K L}+\alpha_{L} \varepsilon_{L L}=0$ ). The amount of redistribution between the native production factors should be in line with these price effects. We now discuss three approximation methods: two proposed by Borjas, and one proposed by us. 
Method 1 (Borjas; 1999, section 2.1) uses the linear approximation to calculate the total loss in earnings of workers: $\left(w_{0}-w_{1}\right) \approx-(\partial w / \partial L) M$. The loss is approximated as follows:

$$
\frac{N\left(w_{1}-w_{0}\right)}{Q} \approx \alpha_{L} \varepsilon_{L L} m(1-m)
$$

The gain of capital owners is calculated as a remainder by adding up the absolute value of the loss of workers and the immigration surplus. In the example of Table 2.1 the total loss in earnings of workers is $1.89 \%$ of GDP and the total gain in earnings of capital owners is $2.00 \%$ of GDP. As the capital share in national income is $30 \%$, the increase in the earnings of capital is $6.67 \%$ (2.00\% divided by 0.3$)$ and not $7.00 \%$ as one would expect.

Method 2 (Borjas; 1999, section 2.2) is based on the notion that when the partial derivatives of factor prices $\partial r / \partial M$ and $\partial w / \partial M$ are evaluated at the initial equilibrium, without immigration, the infinitesimal increase in national income accruing to natives is zero (Bagwati and Srivivasan, 1993). To calculate finite changes, we evaluate the immigration surplus using an 'average' rate for the partial derivatives. The averages are defined by:

$$
\begin{aligned}
& \frac{\partial r}{\partial M} \approx \frac{1}{2}\left(\left.\frac{\partial r}{\partial M}\right|_{L=N}+\left.\frac{\partial r}{\partial M}\right|_{L=N+M}\right) \\
& \frac{\partial w}{\partial M} \approx \frac{1}{2}\left(\left.\frac{\partial w}{\partial M}\right|_{L=N}+\left.\frac{\partial w}{\partial M}\right|_{L=N+M}\right)
\end{aligned}
$$

Borjas (1999) applies this notion to the case of an economy with three production factors; we discuss this economy in the next section. In practice, Borjas 'averages' the price effects of immigration leading to effects of immigration that are too small. The example of Table 2.1 shows that the changes in earnings are halved compared to the results on the basis of the labour supply elasticities.

Note that for both methods 1 and 2, we need to multiply the change in earnings of capital by the capital share in national income (30\%) to get change in total native earnings. To get the change in total native earnings of labour, we need to multiply the change in earnings by the labour share in national income $(70 \%)$ and by the native population share $(0.9)$.

Method 3 is our own proposal: as we believe that the elasticities of factor prices, $\varepsilon_{K L}$ and $\varepsilon_{L L}$, should be used to approximate the price effects of immigration, we need to find weighting factors for equation (2.4) that give the immigration surplus of equation (2.2). Define: 
$\frac{\Delta Q_{N}}{Q} \approx \alpha_{K}^{*}\left[\frac{\partial r}{\partial M} \frac{M}{r}\right]+\alpha_{L}^{*}\left[\frac{\partial w}{\partial M} \frac{M}{w}\right]$

with $\alpha_{i}{ }^{*}=\left(\alpha_{i}^{0}+\alpha_{i}^{m}\right) / 2(i=K, L)$ where $\alpha_{i}^{0}$ is the share in national income of natives assuming that all inhabitants are natives $\left(\alpha_{K}{ }^{0}=\alpha_{K}\right.$ and $\left.\alpha_{L}{ }^{0}=\alpha_{L}\right)$ and $\alpha_{i}{ }^{m}$ is the share in national income of natives assuming that a fraction $m$ of workers are immigrants $\left(\alpha_{K}{ }^{m}=\alpha_{K}\right.$ and $\left.\alpha_{L}{ }^{m}=(1-m) \alpha_{L}\right)$. So where method 2 averages the price effects of immigration, our method averages the weighting factors. It can be shown that equation (2.8) leads to the immigration surplus of equation (2.2).

According to method 3, the effect of immigration on the earnings are by definition equal to the effect on basis of the elasticities, see Table 2.1. Method 1 gives outcomes that are close to the outcomes of method 3. As both methods are approximations, it is not possible to draw conclusions on the accuracy of the two methods. The only disadvantage of method 1 is its arbitrariness: the gains of capital owners are calculated as a remainder term, but one could as well calculate the loss of the workers as a remainder term.

Though the three methods differ with respect to the effects of immigration on earnings of labour and capital, they all generate the same immigration surplus. Methods 1 and 3 give price effects of immigration that are (approximately) equal to effects of the basis of the elasticities. Method 2 gives a kind of 'average' price effect of immigration.

In this section, we assumed the stock of capital to be fixed. If the stock of capital would be perfectly elastic, the stock of capital adjusts such that the price of capital remains unchanged. As a consequence, wages remain unchanged and the immigration surplus is zero. This result may change, however, when there more than two production factors.

\section{Model with three production factors}

Suppose there are two types of workers in the host country's labour market, skilled $\left(L_{s}\right)$ and unskilled $\left(L_{u}\right)$. The linear homogenous production function is given by

$Q=f\left(K, L_{s}, L_{U}\right)=f[k, b N+\beta M,(1-b) N+(1-\beta) M]$

where $b$ and $\beta$ denote the fraction of skilled workers among natives and among immigrants. The production function is twice differentiable, with $f_{i}>0$ and $f_{i}<0\left(i=K, L_{s}, L_{u}\right)$. The price of each factor of production, $r$ for capital and $w_{i}(i=S, U)$ for labour, is determined by the respective marginal productivity condition. 
We consider two kinds of economies: one economy with a fixed stock of capital (i.e. perfectly inelastic capital) and one with a flexible stock of capital (e.g. perfectly elastic capital).

\section{Inelastic capital}

Suppose that the stock of capital is fixed and owned by natives. Like for the case with two production factors, the rental rate of capital will change because of immigration. Expressed as a fraction of GDP the immigration surplus consists of the net changes in incomes of capital owners and the different types of native workers:

$\frac{\Delta Q_{N}}{Q}=\frac{K\left(r_{1}-r_{0}\right)}{Q}+\frac{b N\left(w_{s 1}-w_{s 0}\right)}{Q}+\frac{(1-b) N\left(w_{u 1}-w_{u 0}\right)}{Q}$

The changes in total earnings of capital owners and of workers can be approximated by using the same methods as used in the Section 2. The immigration surplus can again be written as a weighted sum of the immigration elasticities of factor prices:

$\frac{\Delta Q_{N}}{Q} \approx \alpha_{K}^{*}\left[\frac{\partial r}{\partial M} \frac{M}{r}\right]+\alpha_{S}^{*}\left[\frac{\partial w_{S}}{\partial M} \frac{M}{w_{S}}\right]+\alpha_{U}^{*}\left[\frac{\partial w_{U}}{\partial M} \frac{M}{w_{U}}\right]$

with weighting factors $\alpha_{i}^{*}(i=K, S, U)$. Equations (15) to (17) of Borjas (1999) report the expressions for the immigration elasticities.

Borjas employs method 2 to calculate the immigration surplus and the price effects. In other words, he uses an 'average' rate for the partial derivatives $\partial r / \partial M, \partial w_{S} / \partial M$ and $\partial w_{S} / \partial M$ and as a consequence he halves the immigration elasticities. His weighting factors are equal to $\alpha_{K}{ }^{*}=\alpha_{K}$, $\alpha_{S}{ }^{*}=\alpha_{S}(1-m)\left(b / p_{S}\right)$ and $\alpha_{U}{ }^{*}=\alpha_{U}(1-m)\left((1-b) / p_{U}\right)$ with $p_{S}$ and $p_{U}$ the shares of the work force that are skilled and unskilled.

We employ method 3, implying that the weighting factors are: $\alpha_{i}{ }^{*}=\left(\alpha_{i}{ }^{0}+\alpha_{i}{ }^{m}\right) / 2(i=K, S, U)$ where $\alpha_{i}^{0}$ is the share in national income of natives assuming that all inhabitants are natives $\left(\alpha_{K}{ }^{0}=\alpha_{K}\right.$, $\alpha_{S}{ }^{0}=\alpha_{S}$ and $\left.\alpha_{U}{ }^{0}=\alpha_{U}\right)$ and $\alpha_{i}{ }^{m}$ is the share in national income of natives assuming that a fraction $m$ of workers are immigrants $\left(\alpha_{K}{ }^{m}=\alpha_{K}, \alpha_{S}{ }^{m}=\alpha_{S}(1-m)\left(b / p_{S}\right), \alpha_{U}{ }^{m}=\alpha_{U}(1-m)\left((1-b) / p_{U}\right)\right)$. Appendix A proves that the immigration surpluses of methods 2 and 3 are equal to each other.

\section{Elastic capital}

In this economy the stock of capital adjusts such that the rental rate of capital does not change. To determine the impact of immigration on the earnings of the two types of labour we need to know how the stock of capital adjusts. We know that 


$$
\begin{aligned}
& \frac{\partial r}{\partial M}=\frac{\partial f_{K}}{\partial M}=f_{K K} \frac{\partial K}{\partial M}+f_{K S} \beta+f_{K U}(1-\beta)=0 \\
& \frac{\partial K}{\partial M} \frac{M}{K}=-\frac{\beta f_{K S}+(1-\beta) f_{K U}}{f_{K K}} \frac{M}{K}
\end{aligned}
$$

The immigration elasticities of wages can be derived under the condition that equation (3.5) holds, see equations (10) and (11) of Borjas (1999). The immigration surplus can again be written as a weighted sum of the immigration elasticities:

$$
\frac{\Delta Q_{N}}{Q} \approx \alpha_{S}^{*}\left[\left.\frac{\partial w_{S}}{\partial M} \frac{M}{w_{S}}\right|_{\partial r / \partial M=0}\right]+\alpha_{U}^{*}\left[\left.\frac{\partial w_{U}}{\partial M} \frac{M}{w_{U}}\right|_{\partial r / \partial M=0}\right]
$$

To calculate the immigration surplus, Borjas employs method 2 while we employ method 3. In both cases the weigthing factors are the same as for the economy with inelastic capital. One can proof that the immigration surpluses of methods 2 and 3 are equal, see Appendix A.

\section{Simulations}

To illustrate the differences between the two methods we provide simulations that extent the 'back-of-the-envelope' calculations of Section 2. To do this, we need to aggregate the labour market into two skill groups. We follow the second example of Borjas (1999), which is based on high-school and college equivalents in the US labour market. Using data from the Current Population Survey, he reports that $43 \%$ and $33 \%$ of the work force and the immigrant workers are high skilled ( $p_{s}=0.43$ and $\beta=0.33$ ), and that the share of income accruing to skilled and to unskilled workers equal $37.1 \%$ and $32.9 \%\left(\alpha_{S}=0.371\right.$ and $\left.\alpha_{U}=0.329\right)$.

The outcomes of the simulations will crucially depend on the responsiveness of factor prices to increases in labour supply. Borjas used the following range for the vector $\left(\varepsilon_{S S}, \varepsilon_{U U}\right):(-0.5,-0.3)$, $(-0.9,-0.6)$, and $(-1.5,-0.8)$. The cross elasticity $\varepsilon_{S U}$ is set to 0.05 in all simulations. Because an elasticity matrix needs to fulfil two identities these assumptions determine all elasticities. ${ }^{4} \mathrm{To}$ give an example, in the case of $\left(\varepsilon_{S S}, \varepsilon_{U U}\right)=(-0.5,-0.3)$ the matrix of elasticities will be as follows:

$E=\left[\begin{array}{lll}\varepsilon_{K K} & \varepsilon_{K S} & \varepsilon_{K U} \\ \varepsilon_{S K} & \varepsilon_{S S} & \varepsilon_{S U} \\ \varepsilon_{U K} & \varepsilon_{U S} & \varepsilon_{U U}\end{array}\right]=\left[\begin{array}{ccc}-0.824 & 0.557 & 0.267 \\ 0.450 & -0.500 & 0.050 \\ 0.244 & 0.056 & -0.300\end{array}\right]$

\footnotetext{
${ }^{4}$ The row-wise sum and the column-wise weighted average of an elasticity matrix should equal zero.
} 
For the economy with inelastic capital, the price effects of immigration can be calculated directly from the elasticity matrix. The reason is that in this economy only prices react to immigration, while quantities stay unchanged (except for changes due to immigration). In the example, a fraction of immigrants in the labour force of $10 \%$ implies that $7.7 \%$ and $11.8 \%$ of skilled and unskilled workers are immigrants $\left(10 \% x\left(\beta / p_{s}\right)\right.$ and $\left.10 \% x(1-\beta) /\left(1-p_{s}\right)\right)$. The price effect of immigration is then as follows:

$\left[\begin{array}{c}\partial \ln (r) \\ \partial \ln \left(w_{S}\right) \\ \partial \ln \left(w_{U}\right)\end{array}\right]=E \times\left[\begin{array}{c}\partial \ln (K) \\ \partial \ln \left(L_{S}\right) \\ \partial \ln \left(L_{U}\right)\end{array}\right]=E \times\left[\begin{array}{c}0.000 \\ 0.077 \\ 0.118\end{array}\right]=\left[\begin{array}{c}0.074 \\ -0.033 \\ -0.031\end{array}\right]$

According to the elasticity matrix, immigration decreases wages of skilled and unskilled workers by $3.3 \%$ and $3.1 \%$. The rental rate of capital increases by $7.4 \%$. The effects of immigration in an economy with inelastic capital cannot be derived directly from the elasticity matrix $E$ as the quantity of capital adjusts (instead of the rental rate of capital).

Table 3.1 Simulation of economic costs and benefits from immigration ${ }^{\mathrm{a}, \mathrm{b}}$

\begin{tabular}{|c|c|c|c|c|}
\hline & Meth & & Met & \\
\hline & Capital & Capital & Capital & Capital \\
\hline & Inelastic & Elastic & Inelastic & Elastic \\
\hline Assume $\left(\varepsilon_{\underline{S S}} \underline{\underline{\varepsilon}} \underline{\underline{u}}\right)=(-0.5,-0.3)$ & & & & \\
\hline Earnings of capital & 3,71 & & 7,41 & \\
\hline Earnings of skilled labour & $-1,50$ & 0,37 & $-3,25$ & 0,80 \\
\hline Earnings of unskilled labour & $-1,36$ & $-0,40$ & $-3,09$ & $-0,90$ \\
\hline Immigration surplus & 0,11 & 0,01 & 0,11 & 0,01 \\
\hline Assume $\left(\varepsilon_{\underline{s S}} \underline{\varepsilon} \underline{\underline{u}}\right)=(-0.9,-0.6)$ & & & & \\
\hline Earnings of capital & 7,54 & & 15,07 & \\
\hline Earnings of skilled labour & $-2,92$ & 0,67 & $-6,32$ & 1,46 \\
\hline Earnings of unskilled labour & $-2,92$ & $-0,73$ & $-6,62$ & $-1,65$ \\
\hline Immigration surplus & 0,22 & 0,01 & 0,22 & 0,01 \\
\hline Assume $\left(\varepsilon_{\underline{S S}} \underline{\underline{\varepsilon}} \underline{u U}\right)=(-1.5,-0.8)$ & & & & \\
\hline Earnings of capital & 11,67 & & 23,35 & \\
\hline Earnings of skilled labour & $-5,04$ & 0,95 & 10,92 & 2,05 \\
\hline Earnings of unskilled labour & $-3,96$ & $-1,02$ & $-8,97$ & $-2,32$ \\
\hline Immigration surplus & 0,33 & 0,02 & 0,33 & 0,02 \\
\hline
\end{tabular}


Table 3.1 presents the full set of simulations. The outcomes of equation (3.8) are reported in the third column of the upper panel. For the same case, Borjas reports that wages of skilled and unskilled workers decrease by only $1.5 \%$ and $1.4 \%$. The difference between the two methods is larger than a factor 2 ; see footnote $\mathrm{c}$ of Table 3.1. If capital is perfectly elastic the change in wages is substantially smaller, but the difference between the two methods remains.

For the case with large elasticities $\left(\varepsilon_{S S}, \varepsilon_{U U}\right)=(-1.5,-0.8)$, unskilled workers experience a decline in wages of about $9.0 \%$ (inelastic capital) or $2.3 \%$ (elastic capital) according to Method 3 . Method 2 gives a decline of about $4.0 \%$ or $1.0 \%$. To our opinion, the difference is rather substantial and thus clearly underreports the impact of immigration on wages.

\section{$4 \quad$ Conclusions}

In this paper, we study gains and losses that accrue to natives because of immigration. The gain of the aggregated level is called the 'immigration surplus', which can be seen as analogous to a consumer surplus. While welfare analyses often do not investigate redistributive effects as they are mostly based on partial models, we employ a stylized model that allows us to investigate the impact of immigration on the earnings of all production factors. Surprisingly, it turns out to be less than straightforward to tally up the changes in earnings to the immigration surplus. We propose a method that deviates from Borjas (1999).

We employ a stylized model with three production factors: capital and two types of labour. We assume natives and immigrants to be perfect substitutes in production within a type of labour. Like Borjas, we find that the immigration surplus is small compared to the amounts involved in redistribution between natives. We find, however, that the amounts involved in redistribution are substantially larger than reported by Borjas.

\section{Literature}

Borjas, G. J. (1999), The economic analysis of immigration, in: O. Ashenfelter and d. Card (eds.) Handbook of Labor Economics, Vol. 3, Amsterdan, North-Holland.

Hamermesh, D. (1993), Labor Demand, Princeton University Press, Princeton

Baghwati, J. N. and T. N. Srinivasan (1983), Lecture on international trade, The MIT Press, Cambridge, MA. 


\section{Appendix A: Immigration surpluses}

In the economy with three production factors and with capital being inelastic, the immigration surpluses according to methods 2 and 3 are equal. Take the immigration surplus according to Method 3:

$$
\left.\frac{\Delta Q_{N}}{Q}\right|_{\text {method } 3}=\frac{1}{2}\left(\alpha_{K}^{0}+\alpha_{K}^{m}\right)\left[\frac{\partial r}{\partial M} \frac{M}{r}\right]+\frac{1}{2}\left(\alpha_{S}^{0}+\alpha_{S}^{m}\right)\left[\frac{\partial w_{S}}{\partial M} \frac{M}{w_{S}}\right]+\frac{1}{2}\left(\alpha_{U}^{0}+\alpha_{U}^{m}\right)\left[\frac{\partial w_{U}}{\partial M} \frac{M}{w_{U}}\right]
$$

Next, we split the expression up according to the two different kinds of weighting factors:

$$
\begin{aligned}
\left.\frac{\Delta Q_{N}}{Q}\right|_{\operatorname{method} 3}= & \frac{1}{2}\left(\alpha_{K}^{0}\left[\frac{\partial r}{\partial M} \frac{M}{r}\right]+\alpha_{S}^{0}\left[\frac{\partial w_{S}}{\partial M} \frac{M}{w_{S}}\right]+\alpha_{S}^{0}\left[\frac{\partial w_{U}}{\partial M} \frac{M}{w_{U}}\right]\right)+ \\
& \frac{1}{2}\left(\alpha_{K}^{m}\left[\frac{\partial r}{\partial M} \frac{M}{r}\right]+\alpha_{S}^{m}\left[\frac{\partial w_{S}}{\partial M} \frac{M}{w_{S}}\right]+\alpha_{U}^{m}\left[\frac{\partial w_{U}}{\partial M} \frac{M}{w_{U}}\right]\right)
\end{aligned}
$$

The crucial part of the proof is that the first part of the equation is zero. The three immigration elasticities of prices are linear functions of the labour supply elasticities $\varepsilon_{i j}(i, j=K, S, U)$, see equation (15) to (17) of Borjas (1999). As the weighting factors are defined $\alpha_{i}^{0}=\alpha_{i}(i=K, S, U)$, the first part of the equation is zero because of the identity $\alpha_{K} \varepsilon_{K i}+\alpha_{S} \varepsilon_{S}+\alpha_{U} \varepsilon_{U i}=O(i=K, S, U)$. This gives:

$$
\left.\frac{\Delta Q_{N}}{Q}\right|_{\text {method } 3}=\frac{1}{2}\left(\alpha_{K}^{m}\left[\frac{\partial r}{\partial M} \frac{M}{r}\right]+\alpha_{S}^{m}\left[\frac{\partial w_{S}}{\partial M} \frac{M}{w_{S}}\right]+\alpha_{U}^{m}\left[\frac{\partial w_{U}}{\partial M} \frac{M}{w_{U}}\right]\right)
$$

Reshuffling of the parameters gives:

$$
\begin{aligned}
\left.\frac{\Delta Q_{N}}{Q}\right|_{\text {method } 3} & =\alpha_{K} \frac{1}{2}\left[\frac{\partial r}{\partial M} \frac{M}{r}\right]+\alpha_{S}(1-m)\left(\frac{b}{p_{S}}\right) \frac{1}{2}\left[\frac{\partial w_{S}}{\partial M} \frac{M}{w_{S}}\right]+\alpha_{U}(1-m)\left(\frac{1-b}{p_{U}}\right) \frac{1}{2}\left[\frac{\partial w_{U}}{\partial M} \frac{M}{w_{U}}\right] \\
& =\left.\frac{\Delta Q_{N}}{Q}\right|_{\text {method } 2}
\end{aligned}
$$

The proof for the immigration surpluses with elastic capital is analogous 


\section{IZA Discussion Papers}

\begin{tabular}{|c|c|c|c|c|}
\hline No. & Author(s) & Title & Area & Date \\
\hline 903 & $\begin{array}{l}\text { S. Girma } \\
\text { H. Görg }\end{array}$ & $\begin{array}{l}\text { Evaluating the Causal Effects of Foreign } \\
\text { Acquisition on Domestic Skilled and Unskilled } \\
\text { Wages }\end{array}$ & 2 & $10 / 03$ \\
\hline 904 & $\begin{array}{l}\text { S. P. Jenkins } \\
\text { P. Van Kerm }\end{array}$ & $\begin{array}{l}\text { Trends in Income Inequality, Pro-Poor Income } \\
\text { Growth and Income Mobility }\end{array}$ & 1 & $10 / 03$ \\
\hline 905 & $\begin{array}{l}\text { D. Weichselbaumer } \\
\text { R. Winter-Ebmer }\end{array}$ & $\begin{array}{l}\text { Rhetoric in Economic Research: The Case of } \\
\text { Gender Wage Differentials }\end{array}$ & 7 & $10 / 03$ \\
\hline 906 & $\begin{array}{l}\text { D. Weichselbaumer } \\
\text { R. Winter-Ebmer }\end{array}$ & $\begin{array}{l}\text { A Meta-Analysis of the International Gender } \\
\text { Wage Gap }\end{array}$ & 7 & $10 / 03$ \\
\hline 907 & $\begin{array}{l}\text { A. Dupuy } \\
\text { L. Borghans }\end{array}$ & $\begin{array}{l}\text { Supply and Demand, Allocation and Wage } \\
\text { Inequality: An International Comparison }\end{array}$ & 1 & $10 / 03$ \\
\hline 908 & M. Leonardi & Product Demand Shifts and Wage Inequality & 1 & $10 / 03$ \\
\hline 909 & M. Leonardi & $\begin{array}{l}\text { Firm Heterogeneity in Capital/Labor Ratios and } \\
\text { Wage Inequality }\end{array}$ & 1 & $10 / 03$ \\
\hline 910 & $\begin{array}{l}\text { P. Díaz-Vázquez } \\
\text { D. Snower }\end{array}$ & $\begin{array}{l}\text { On-the-Job Training, Firing Costs and } \\
\text { Employment }\end{array}$ & 5 & $10 / 03$ \\
\hline 911 & J. Wagner & $\begin{array}{l}\text { Are Nascent Entrepreneurs Jacks-of-all-Trades? } \\
\text { A Test of Lazear's Theory of Entrepreneurship } \\
\text { with German Data }\end{array}$ & 5 & $10 / 03$ \\
\hline 912 & $\begin{array}{l}\text { D. Checchi } \\
\text { A. Filippin }\end{array}$ & An Experimental Study of the POUM Hypothesis & 1 & $10 / 03$ \\
\hline 913 & $\begin{array}{l}\text { S. Pivnenko } \\
\text { D. DeVoretz }\end{array}$ & $\begin{array}{l}\text { The Recent Economic Performance of Ukrainian } \\
\text { Immigrants in Canada and the U.S. }\end{array}$ & 1 & $10 / 03$ \\
\hline 914 & $\begin{array}{l}\text { A. R. Cardoso } \\
\text { P. Portugal }\end{array}$ & $\begin{array}{l}\text { Bargained Wages, Wage Drift and the Design of } \\
\text { the Wage Setting System }\end{array}$ & 5 & $10 / 03$ \\
\hline 915 & $\begin{array}{l}\text { R. Hujer } \\
\text { C. Zeiss }\end{array}$ & $\begin{array}{l}\text { Macroeconomic Impacts of ALMP on the } \\
\text { Matching Process in West Germany }\end{array}$ & 6 & $10 / 03$ \\
\hline 916 & $\begin{array}{l}\text { S. C. Wolter } \\
\text { S. Mühlemann } \\
\text { J. Schweri }\end{array}$ & $\begin{array}{l}\text { Why Some Firms Train Apprentices and Many } \\
\text { Others Do Not }\end{array}$ & 5 & $10 / 03$ \\
\hline 917 & $\begin{array}{l}\text { R. Euwals } \\
\text { H. Roodenburg }\end{array}$ & $\begin{array}{l}\text { A Note on the Redistributive Effect of } \\
\text { Immigration }\end{array}$ & 1 & $10 / 03$ \\
\hline
\end{tabular}

An updated list of IZA Discussion Papers is available on the center's homepage www.iza.org. 